\title{
Response of the Banda Sea to the southeast monsoon
}

\author{
Thomas Surman Moore $\mathrm{II}^{1,2, *}$, John Marra $^{2}$, Ali Alkatiri ${ }^{3}$ \\ ${ }^{1}$ CSIRO DMR, GPO Box 1538, Hobart, Tasmania, 7000 Australia \\ ${ }^{2}$ Lamont-Doherty Earth Observatory (LDEO) of Columbia University, Palisades, New York 10964-8000, USA \\ ${ }^{3}$ Agency for the Assessment and Application of Technology (BPPT), Jakarta 10340, Indonesia
}

\begin{abstract}
Three mechanisms are suggested to describe the physical response in the Banda Sea to the seasonal winds of the southeast monsoon: basin-wide wind-induced mixing, upwelling primarily on the eastern side, and a more complex basin circulation. We use the distribution of chl $a$ in the Banda Sea, from both shipboard and satellite data, as an indicator of the dominant mechanism. An east-west transect of stations through the central Banda Sea in September 1998 shows higher phytoplankton biomass to the east, suggesting a remnant upwelling signal from the southeast monsoon in the previous months. Phytoplankton pigment data indicate a community dominated by diatoms to the east, and a more oligotrophic community (e.g. cyanobacteria) to the west. Furthermore, satellite

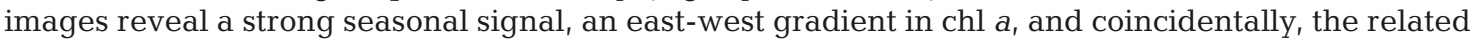
impact of the 1997-1998 El Niño. Overall, the bio-optical data support the idea that the Banda Sea responds to the southeast monsoon through upwelling in the eastern part of the basin.
\end{abstract}

KEY WORDS: Monsoons $\cdot$ Upwelling $\cdot$ Indonesian Seas $\cdot$ ENSO $\cdot$ Ocean Color

\section{INTRODUCTION}

The Indonesian Archipelago is unique in that it represents the only low latitude inter-ocean connection on the planet, with the Indonesian Through Flow (ITF) communicating between the Pacific and Indian Oceans. The seas of the Indonesian Archipelago (Fig. 1) form an artery carrying tropical thermocline water from the Pacific to the Indian Ocean (Wyrtki 1957, 1961, 1987, Gordon 1986). The ITF is driven by the inter-ocean pressure gradient and is primarily contained in the upper layers, possibly entirely above $200 \mathrm{~m}$, and certainly within the top $500 \mathrm{~m}$ (Ilahude \& Gordon 1996). The ITF seems to reach its maximum during the southeast monsoon (SEM, approximately June to September) and its minimum during the northwest monsoon (NWM, approximately December to March) (Tomczak \& Godfrey 1994). Under the influence of both monsoon winds and ENSO forcing, the ITF and associated regional properties and dynamics show strong variability on both seasonal and interannual timescales. In relation to winds, precipitation, and sea surface temperature (SST), it has been suggested that complex feedback mechanisms may exist between the monsoons, ENSO events, and the physical dynamics within the Indonesian Seas (Godfrey 1996).

During the NWM, winds force the surface waters into the eastern archipelago, depressing the thermocline, while in the SEM, when dry air is brought from the Australian continent, the eastern seas empty and there is evidence of large-scale upwelling events in the Banda Sea and elsewhere in the archipelago (Wyrtki 1957, 1961, Meyers 1996, Ilahude 1998, Waworuntu et al. 2000, Susanto et al. 2001). Boely et al. (1990) noted an increase in the amplitude of annual sea-surface temperature going from the Flores Sea in the west to the Arafura Sea in the eastern part of Indonesia. These upwelling events are one of the processes thought to control the productivity dynamics of the region, the other possible contributors being the effect of local wind-mixing on the surface layers and tidal mixing from below. Kinkade et al. (1997) found that winddriven mixing was also important to the seasonal dynamics. The action of the wind may still be consistent with Wyrtki's $(1957,1961)$ ideas. Longhurst (1993) suggested that summertime SE winds create a zonal 


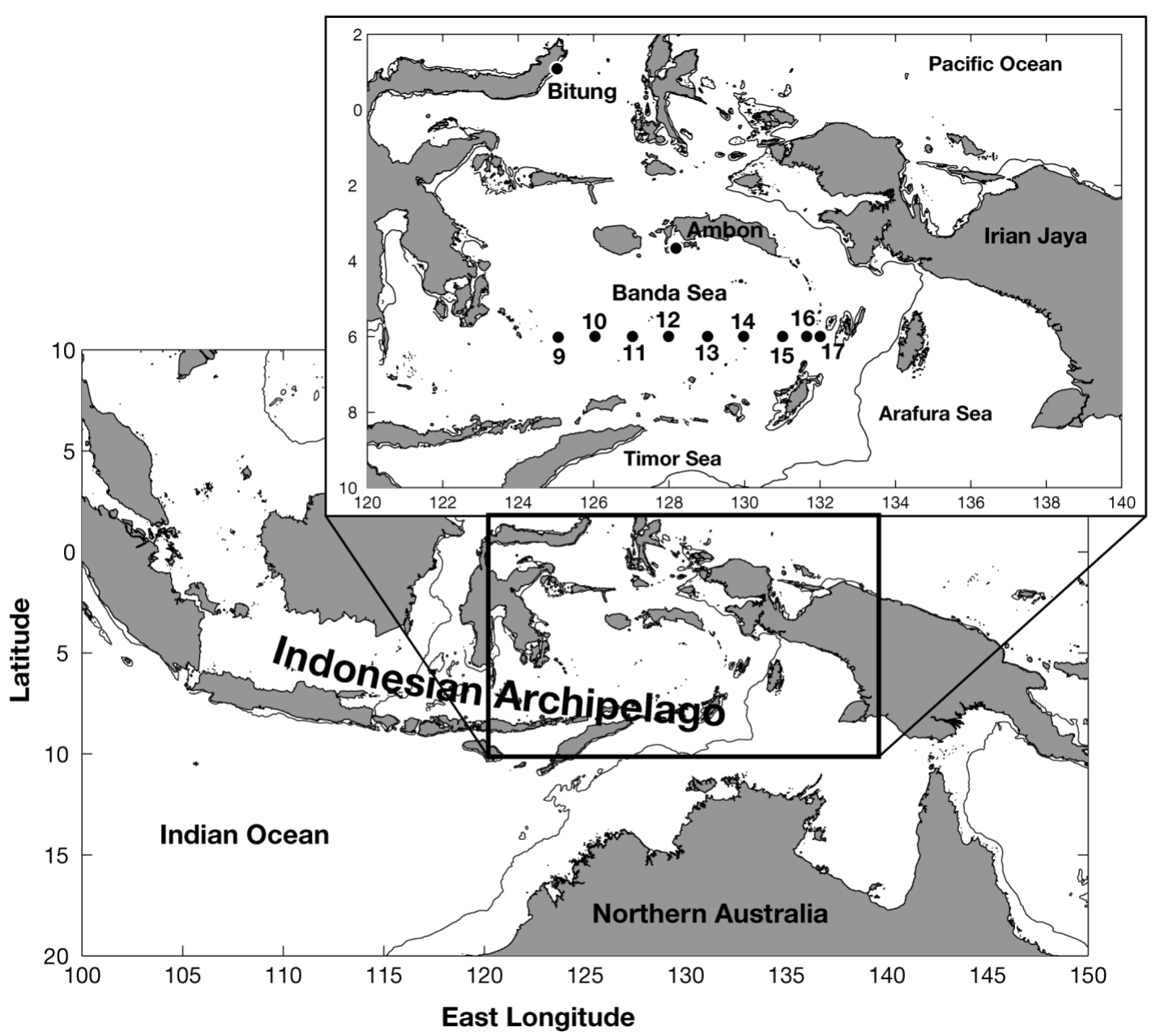

Fig. 1. Eastern Indonesian Seas showing the station positions during BIOP98 (Bio-optical 1998 cruise). RV 'Baruna Jaya IV' left Bitung on 29 September and arrived in Ambon on 10 October. Here we focus on the stations along the $6^{\circ} \mathrm{S}$ transect

wind-stress, which uplifts the thermocline to the east (and depresses it westward). The isotherms of the uplifted thermocline are eroded by the wind, and cool the surface layer. Ffield \& Gordon (1996) made a further case for mixing through the breaking of internal waves, enhanced by wind, and recently Alford \& Gregg (2001) showed a quantitative connection between wind-generated near-inertial waves and mixing in the region. Whatever the mechanism for the 'upwelling', there is an observable decrease in surface temperatures in the Banda Sea during the SE monsoon. The lower temperatures must represent water from depth, and are therefore a marker for a nutrient flux to the surface, a flux that supports an increase in phytoplankton (i.e. chl a) biomass.

Fig. 2 shows the distributions of chl a that we might expect given different controlling processes across the Banda Sea. If local wind-mixing at the surface controls the distribution of productivity in the Banda Sea, we would expect a chl a signal that was fairly uniform from east to west, while an increase from west to east would indicate an upwelling environment. Other patterns of chl a distribution might indicate controls caused by more complex circulation regimes, for example if the SEM set up a gyral circulation in the Banda Sea.

Relatively few data exist for the Indonesian Seas in general, and the Banda Sea in particular. The DutchIndonesian Snellius-II Expedition was conducted in 1984-1985 (see papers in Vol. 25(4) of the Netherlands Journal of Sea Research 1990), with cruises during both the SE (August 1984) and NW (February 1985) monsoons. Relevant contributions to that volume include Gieskes et al. (1990), Zevenboom (1990) and Zijlstra et al. (1990). Snellius-II sampled the eastern Banda and Arafura Seas, that is, from ca. 128 to $138^{\circ} \mathrm{E}$, and compared the SE with the NW monsoons. Here we extend those observations by sampling across the Banda Sea $\left(124\right.$ to $\left.132^{\circ} \mathrm{E}\right)$, in a study of the interaction of the SE monsoon with the ocean surface dynamics. 
The BIOP98 (Bio-optical 1998) cruise was carried out aboard the Indonesian research vessel RV 'Baruna Jaya IV' (hereafter referred to as BJ4). The bulk of the cruise effort took place along an east-west transect line at $6^{\circ} \mathrm{S}$; at roughly the mid-line of the Banda Sea. The timing of this cruise fell later than planned due to logistical obstacles, and this caused us to miss sampling at the height of the SEM as originally planned. Nevertheless, the characteristics of primary production in the Banda Sea are important to the understanding of the fertility and potential resources of the Indonesian Seas in particular, and in general to the productivity of the tropical ocean.

\section{MATERIALS AND METHODS}

During our $12 \mathrm{~d}$ at sea the main focus was to sample a line of 9 stations (Fig. 1) on the mid-basin transect. Along this $6^{\circ} \mathrm{S}$ transect (referred to as 6ST from here on) we endeavored to establish as synoptic a picture as possible of the east-west distribution of oceanic properties and chl a across the Banda Sea.

Onboard the BJ4 we used a suite of instru-
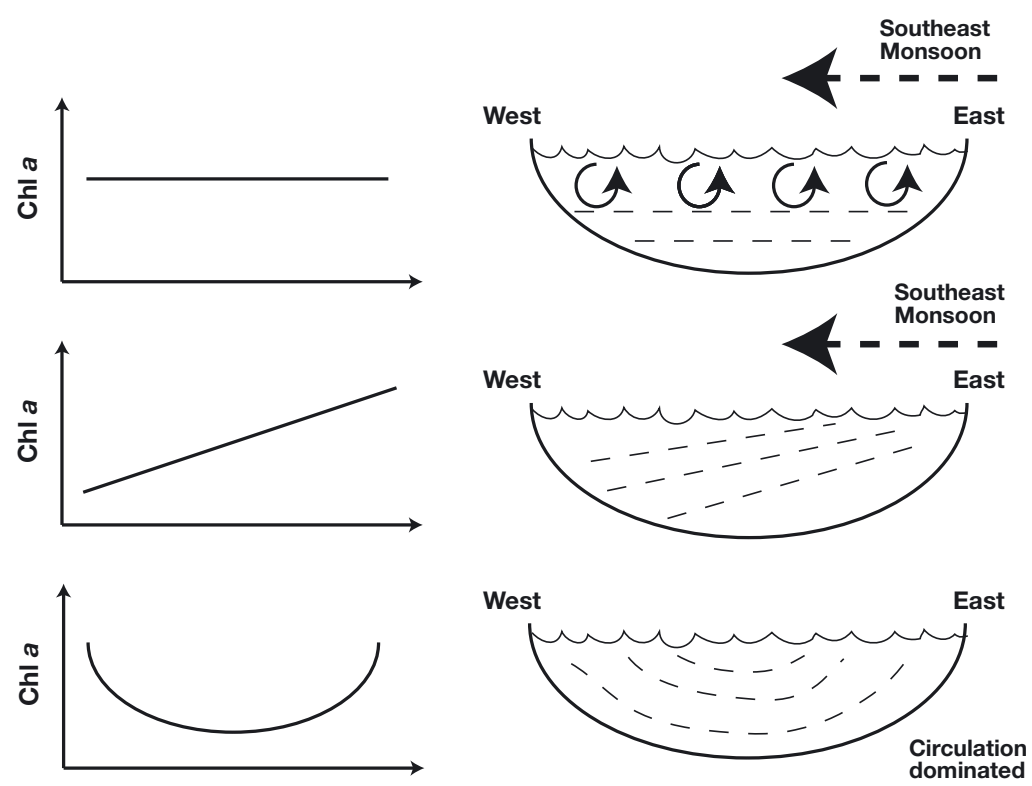

Fig. 2. Hypotheses for the response of the Banda Sea to the SE monsoon. (Dashed lines in right panel are isopycnals.) In the top schematic, the SE monsoon is hypothesized to generate wind-induced mixing, resulting in little or no gradient in chl $a$ in the $\mathrm{E}$ to $\mathrm{W}$ direction. In the middle panel, the SE monsoon is hypothesized to lift isopycnals to the east (upwelling), and the resultant nutrient input to the surface layers would show a chl a distribution increasing in the eastern direction. Finally, in the bottom panel, the SE monsoon is hypothesized to generate an anticyclonic circulation, resulting in an increase in chl $a$ around the edges of the basin ments built around a Marine Environmental Recorder (MER) model 2040 (Biospherical Instr., San Diego). The MER-2040 is a multi-channel spectralradiometer which collects, as a function of depth, downwelling irradiance $E d(z, \lambda)$ and upwelling radiance $L u(z, \lambda)$ (for the 6 wavelengths, 410, 441, 488, $520,565$, and $665 \mathrm{~nm})$, as well as broad-band $\operatorname{PAR}(z)$ (photosynthetically available radiation). A spectrallymatched irradiance sensor was attached to the ship's top deck to measure irradiance above the sea surface, $E d(0, \lambda)$, during the casts. The MER was calibrated before the cruise by the manufacturer, and after the cruise by the Center for Hydro-Optics and Remote Sensing (see, e.g., Mueller et al. 1994, Mueller \& Austin 1995). The profiling system included temperature and conductivity sensors (SeaBird Electronics), a fluorometer (SeaTech) and a beam transmissometer (SeaTech). The SeaBird sensors were calibrated by the manufacturer before the cruise. The in situ fluorometer was calibrated against chl a analysed from samples collected on the cruise. The profiling package was deployed over the starboard rail along the aft quarter of the BJ4 in the direction of the sun, to minimize optical effects caused by the presence of the ship.

Our profiling system allows for 1 water sample to be collected in a Niskin sampler. This sample was collected at the depth of the fluorescence maximum, as

indicated by the shipboard plot of sensor output during the cast. A second sample was collected using a bucket while the profiling system was just beneath the surface of the water. There was some instrument failure and also data problems among the suite of instruments. Here we focus on the successful datasets. The other major data set that has been employed is remotely sensed (satellite) ocean color data from the SeaWiFS sensor (NASA/GSFC).

SeaWiFS Global Area Coverage (GAC) data are on a $9 \mathrm{~km}$ grid, although we also examined $1 \mathrm{~km}$, Local Area Coverage (LAC) scenes to compare with in situ chl a data. The monthly and 8 d composites from September 1997 until December 1998 were examined to determine the variability in space and time of the distribution of chl a. The GAC data used for the composites was generated from SeaWiFS reprocessing \#4 (Patt et al. 2003). A time series of these composites and a quantitative analysis of a cross-section along the 6ST are presented in the 'Results'.

Water samples were taken at the surface and at the approximate depth of the chl a maximum, as evidenced, in situ, by the fluorometer readings during the MER casts. These samples were processed for chl a analysis fluorometrically (JGOFS 1996) using a Turner designs TD700 fluorometer, calibrated with pure chl a 
(Sigma Chem). Samples from each cast were also analysed using a high-performance liquid chromatography (HPLC) method (Wright et al. 1991). The HPLC samples were independently analysed by the Center for Hydrologic Optics and Remote Sensing (CHORS) at San Diego State University, California, USA. Values for chl a obtained with the TD700 agree with total chl a (sum of chlorophyllide $a$, monovinyl chl $a$ and divinyl chl a) from the HPLC method. The regression of fluorometrically determined chl a (fchla) against chl a determined by HPLC (HPLCchla) was HPLCchla = $1.06 \times$ fchla $+0.13\left(\mathrm{r}^{2}=0.88\right)$, with $\mathrm{SE}<5 \%$.

The SeaTech fluorometer was part of every cast of the MER package, and 5 profiles along the 6ST are resolved. Over the entire cruise, 13 successful fluorescence casts were carried out. The values for chl a collected via the Niskin bottle, and in a surface sample during these casts, are fit via a least-squares method versus the fluorometer readings at the bottle depth and at the surface. The regression is $\mathrm{Fl}_{\text {SEATECH }}=$ $2.832 \pm 0.268 \times \mathrm{chl} a+0.371 \pm 0.95$, with $\mathrm{r}^{2}=0.72$. In this way we arrive at a relationship between fluorescence and chl $a$ that is then applied to data for the entire cruise.

\section{RESULTS AND DISCUSSION}

The structure in the temperature cross-section (Fig. 3a) shows no clear upwelling signal. It may have been biased by internal waves, or may be evidence of an internal mixed layer possibly caused by bottom friction and advected from elsewhere (S. Godfrey, CSIRO, pers. comm.). Alternately this section may simply represent the breakdown of the upwelling regime because it was sampled during the transition period between the SEM and the NWM. In contrast to the temperature section along 6ST, the chl a data, derived from in vivo fluorescence, clearly show a shoaling of the chl a maximum and seem to indicate an increase in concentration going from west to east, in accordance with upwelling occurring in the eastern Banda Sea (Fig. 3b). We also have data from the CTD casts for chl a. Although they are not exactly the same as the chl a data derived from the fluorescence profiles (because of differing times, less depth resolution, etc.), these data also show an increase in chl a proceeding from east to west. The depth of the chl a maximum gets shallower, from approximately $75 \mathrm{~m}$ in the west to less than $50 \mathrm{~m}$ in the eastern portion of the Banda Sea. The range in values in chl a that we see are at the low end of those observed during Snellius-II (Gieskes et al. 1990) and those reported in Kinkade et al. (1997), yet it should be taken into account that our data were collected a month later into the monsoon seasonal cycle than those previous observations.

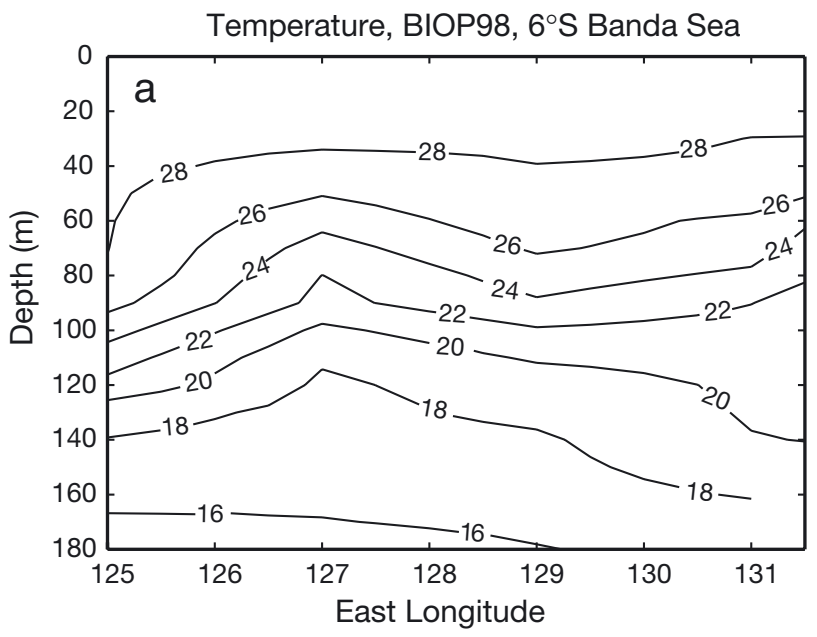

Chlorophyll from fluorescence, BIOP98, 6S Banda Sea

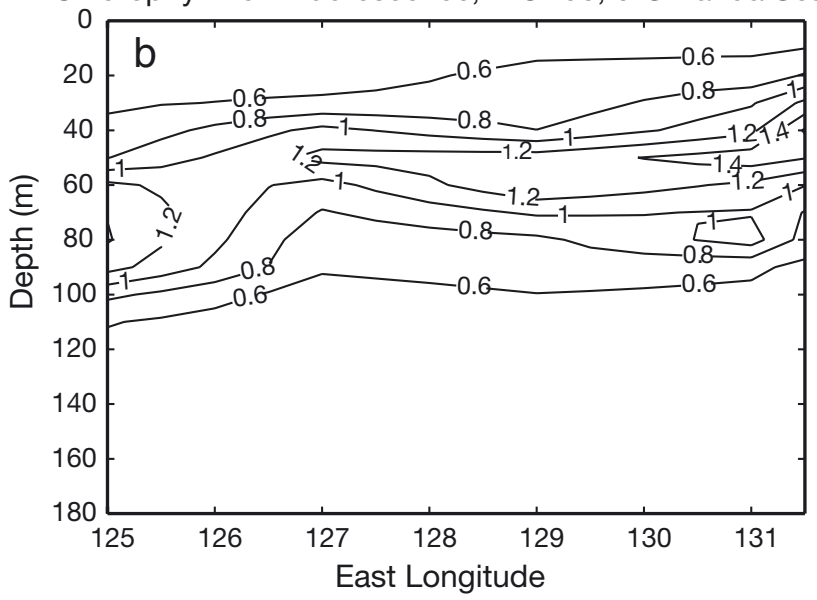

Fig. 3. (a) Distribution of temperature $\left({ }^{\circ} \mathrm{C}\right)$ with depth along the 6ST during BIOP98 (Bio-optical 1998 cruise). (b) Chl a (derived from fluorescence), $6^{\circ} \mathrm{S}$ transect $(6 \mathrm{ST}), \mathrm{BIOP} 98$

Data on other pigments provide further support for upwelling (Wyrtki 1961) in the eastern Banda Sea. We plot these pigments normalized to total chl a as a measure of the proportion of the individual pigment within the phytoplankton community. (For Stn 13, at $129^{\circ} \mathrm{E}$, 2 samples were taken $3 \mathrm{~h}$ apart. Both points are shown for this station in Fig. 4) Fucoxanthin (relative to the total chl a), sampled both at depth and at the surface, across 6ST shows a very marked increase from west to east (Fig. 4a). Fucoxanthin is a strong indicator of the presence of diatoms, which are often associated with upwelling environments, and therefore may indicate a remnant of the SEM. On the other hand, divinyl chl a (DVA), an indicator of Prochlorococcus (Fig. 4b), and zeaxanthin, an indicator of cyanobacteria (Fig. 4c), increase at the surface in the opposite direction, that is, from east to west across 6ST. The data for DVA and zeaxanthin are not as clear as for fucoxanthin, but with 
the exception of the station at $127^{\circ} \mathrm{E}$, the quantities of these pigments are significantly higher to the east in the Banda Sea than to the west. Prochlorophytes and cyanobacteria are usually associated with more nutrient poor, oligotrophic waters.

Comparing ocean color data from the SeaWiFS sensor to our in situ measurements of chl $a$ is not trivial. The algorithms for the remote sensing of marine pigments are still evolving. Mueller \& Austin (1995) state that the SeaWiFS program has an 'uncertainty goal' of $\pm 35 \%$ in chl a concentration and the 4 th SeaWiFS reprocessing, used in this analysis, has in situ chlorophyll match-up errors that range from 23.77 to $31.35 \%$ (S. Bailey, NASA/GSFC, pers. comm.). Preliminary analysis of LAC data taken at the time of the BIOP98 cruise shows reasonable agreement, within the stated uncertainty, given our choice of $1 \mathrm{~km}$ pixel and ship position (C. Ho, LDEO, pers. comm.).

More importantly, on a qualitative level, the SeaWiFS imagery for 1998 shows similar patterns to those seen in the in situ section. The time series of monthly composites from September 1997 until December 1998 shows significant variability in time and space across the study area (Fig. 5). A strong gradient from west to east in remotely sensed chl a concentration develops during the SEM (typically June through September). However, in 1997 the increase in concentration of chl a in the eastern Banda Sea during the SEM seems to last through November (see composite images 9-, 10-, and 11-1997 in Fig. 5), and is also larger in magnitude than the increase during the SEM of 1998 (images 7-, 8-, and 9-1998). In Fig. 6, we have extracted the remotely sensed chl a time series data along $6^{\circ} \mathrm{S}$ from the monthly composites in Fig. 5 and plotted it versus time in months. From this Hofmuller representation, the 1997 and 1998 increases in chl a associated with the SEM are clearly seen, as well as the gradient increasing from west to east in the Banda Sea. The strength of signal in late 1997 and its extended lifespan, compared to 1998 , are also evident.

When the eastern and western bins of remotelysensed chl $a$ are averaged and then plotted versus time, along with the Southern Oscillation Index (SOI; an indicator for the El Niño), a relationship between strength of El Niño and the extended and augmented chl $a$ burst in the eastern Banda Sea becomes evident (Fig. 7). We infer that the strong El Niño that occurred in the Pacific Ocean from mid-1997 to early 1998 intensifies the effect of the SEM on the biological response (as indicated by chl a), at least when compared with the SEM in 1998. It is also apparent that the effect of the monsoon continues later into the year during the El Niño period. The most likely cause for the El Niño 'boost' is that the thermocline shoals over a large region in response to larger scale forcing. However, a
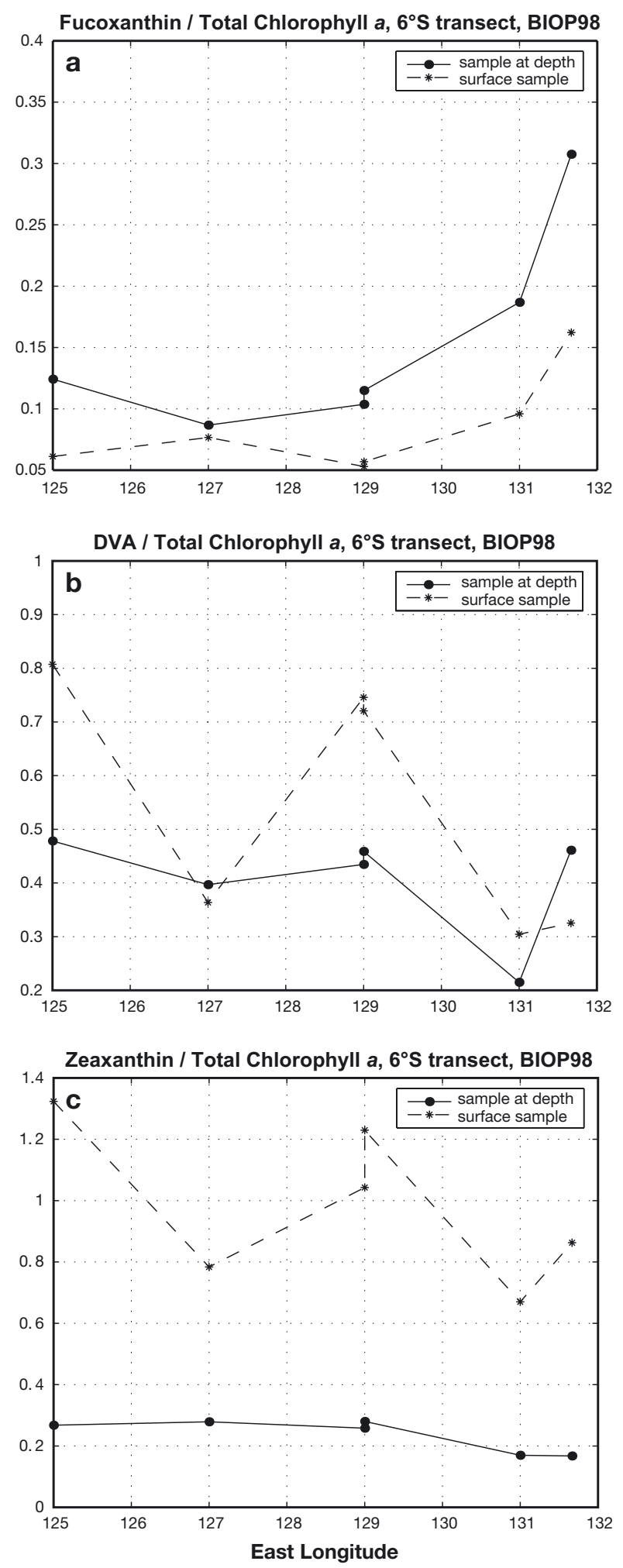

Fig. 4. (a) Fucoxanthin/total chl $a, 6^{\circ} \mathrm{S}$ transect (6ST), BIOP98 (Bio-optical 1998 cruise). Total chl $a$ is defined as the sum of chlorophyllide $a$, monovinyl chl $a$, and divinyl chl a (DVA) (C. Trees, CHORS/SDSU pers. comm.). (b) DVA/total chl $a_{\text {, }}$ 6ST, BIOP98. (c) Zeaxanthin/total chl a, 6ST, BIOP98. Stn 13 at $129^{\circ} \mathrm{E}$ had 2 casts and 2 samples, taken $3 \mathrm{~h}$ apart 

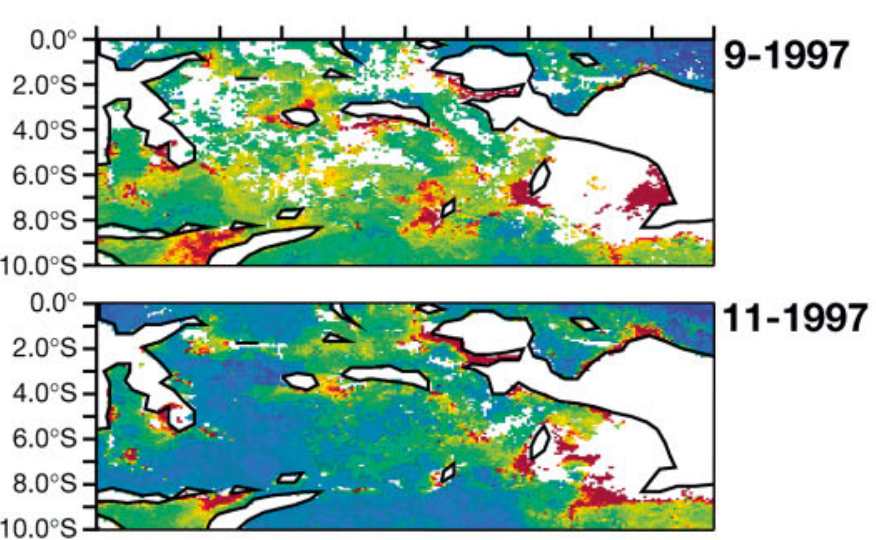

11-1997
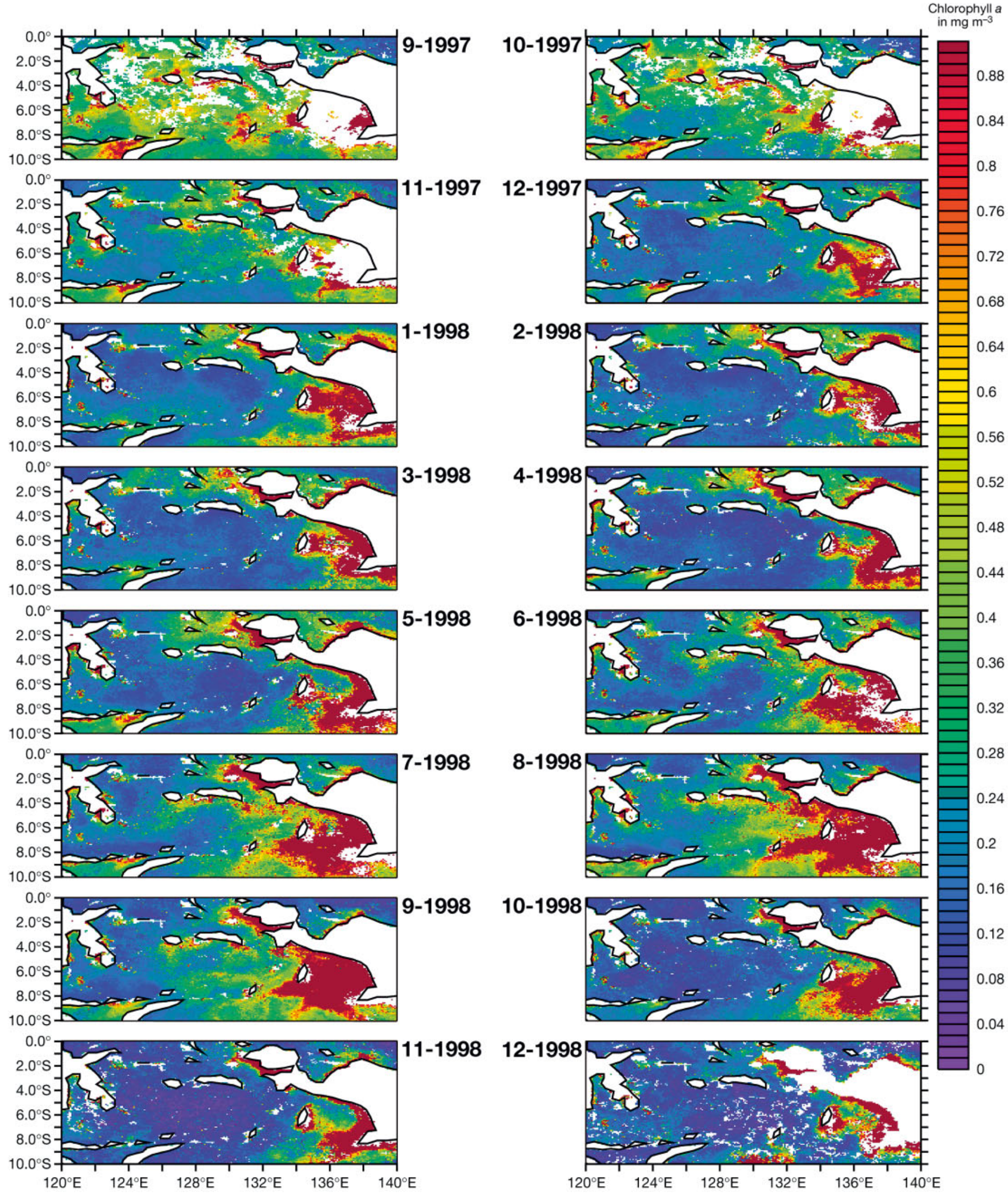

Fig. 5. SeaWiFS monthly composites, September 1997 to December 1998 at 9 km resolution 
change in the monsoonal winds cannot be ruled out. Significant links between ENSO, thermocline depth, and SST have been shown in the Banda Sea and elsewhere in the archipelago (Bray et al. 1996, Ffield \& Gordon 1996, Ffield et al. 2000, Gordon \& Susanto 2001, Susanto et al. 2001, Moore \& Marra 2002). Moore \& Marra (2002) showed that the winds for November 1997 were anomalously from the east, a direction favourable to upwelling. Gordon \& Susanto (2001) showed evidence that the SST minimum during the SEM is delayed under El Niño conditions, although Ekman upwelling is slightly weaker. The relationship between colder SST's, ENSO, and the strength of upwelling transport is probably less straightforward than might have previously been thought.

Other analyses of SST datasets, however, support our findings. Boely et al. (1990) show a stronger SST variation in the eastern Banda Sea in comparison with the west, with the west-east temperature difference

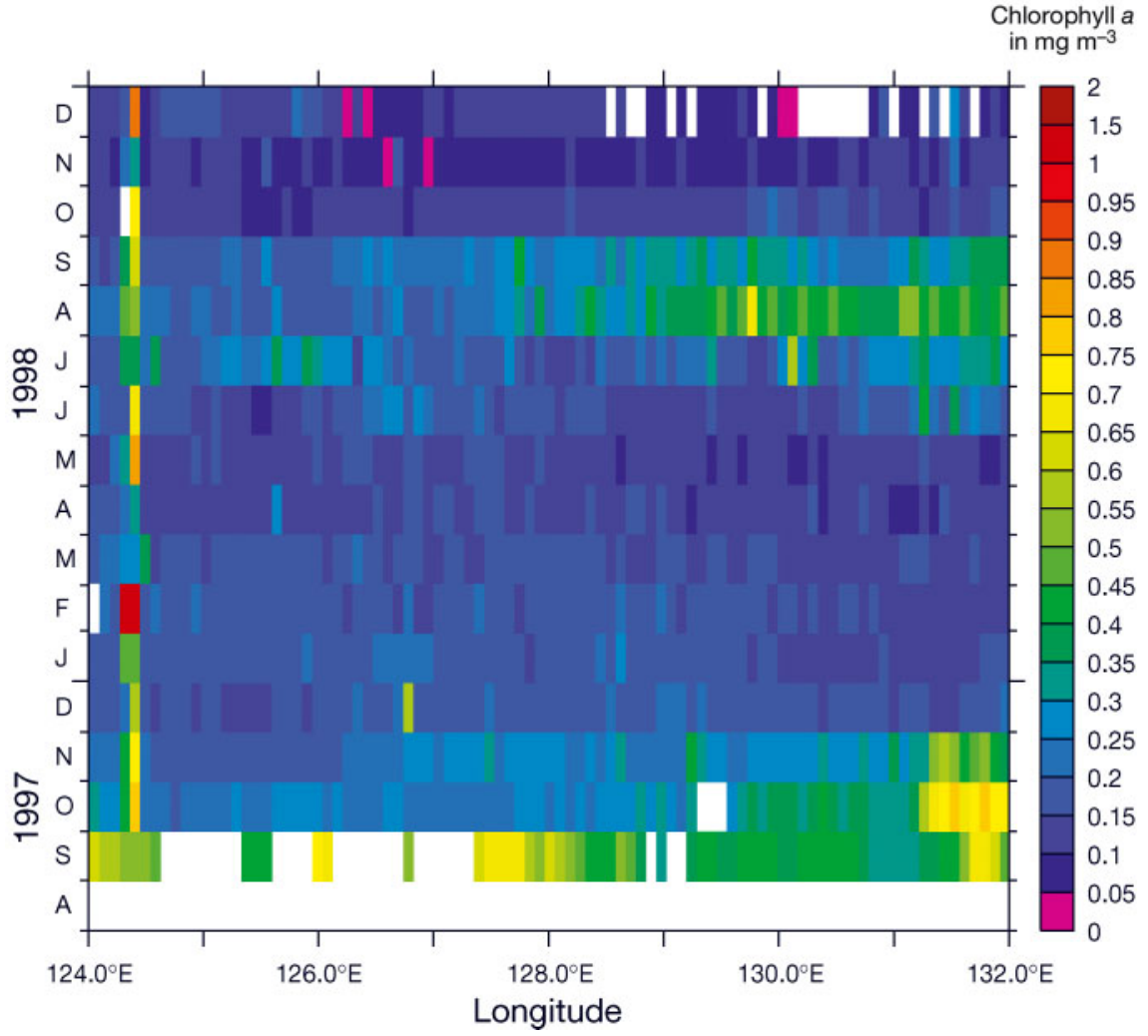

Fig. 6. Hofmuller diagram of remotely sensed chl a along the $6^{\circ} \mathrm{S}$ transect (6ST). These monthly-composite data are taken from SeaWiFS imagery for the time period September 1997 to December 1998 (1998), the authors performed optimal averaging on sea-surface temperature data from the NOAA/NASA Pathfinder satellite. A statistical interpolation was applied to $8 \mathrm{yr}$ of $9 \mathrm{~km}$ resolution AVHRR data in a reanalysis of the Pathfinder dataset. From these data the annual signal was removed and showed clearly that the eastern Banda Sea has much greater annual variability than the west. This region of high annual variability is to the order of $2.5^{\circ} \mathrm{C}$ (Walker \& Wilkin 1998), consistent with the idea that seasonal upwelling occurs there.

The dataset shows further evidence of a difference between the character and dynamics of the eastern and western Banda Sea. While Walker \& Wilkin (1998) show an annual cycle of $2.5^{\circ} \mathrm{C}$ in the eastern Banda, the levels in the western portion of the Banda are only $<1{ }^{\circ} \mathrm{C}$. Ffield \& Gordon (1996) found that the annual cycle of SST in the eastern Banda Sea was on the order of $5^{\circ} \mathrm{C}$ while Gordon \& Susanto (2001) found an annual cycle of $3^{\circ} \mathrm{C}$ for the entire Banda region. Gordon \& Susanto (2001) also showed, from weekly data averaged over a grid-size of $1 \times 1^{\circ}$, that the highest standard

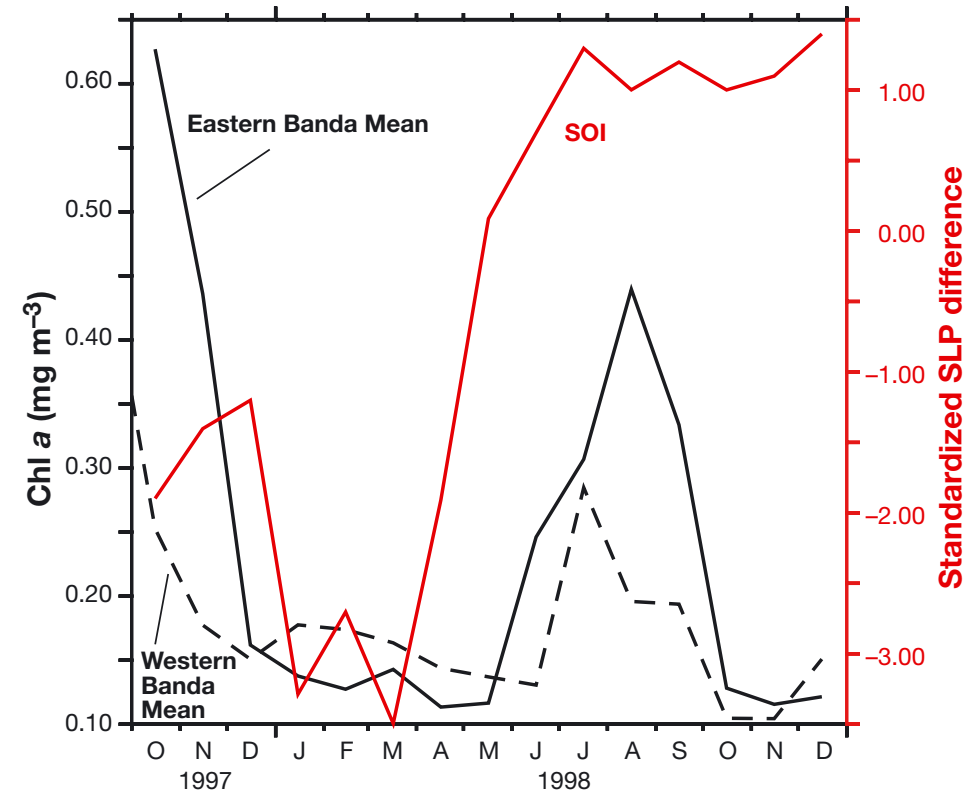

Fig. 7. Chl $a$, averaged for the eastern (black solid line) and western Banda Sea (black dashed line) compared with the Southern Oscillation Index (SOI; red solid line). A negative SOI is associated with an El Niño period. SLP: sea level pressure 


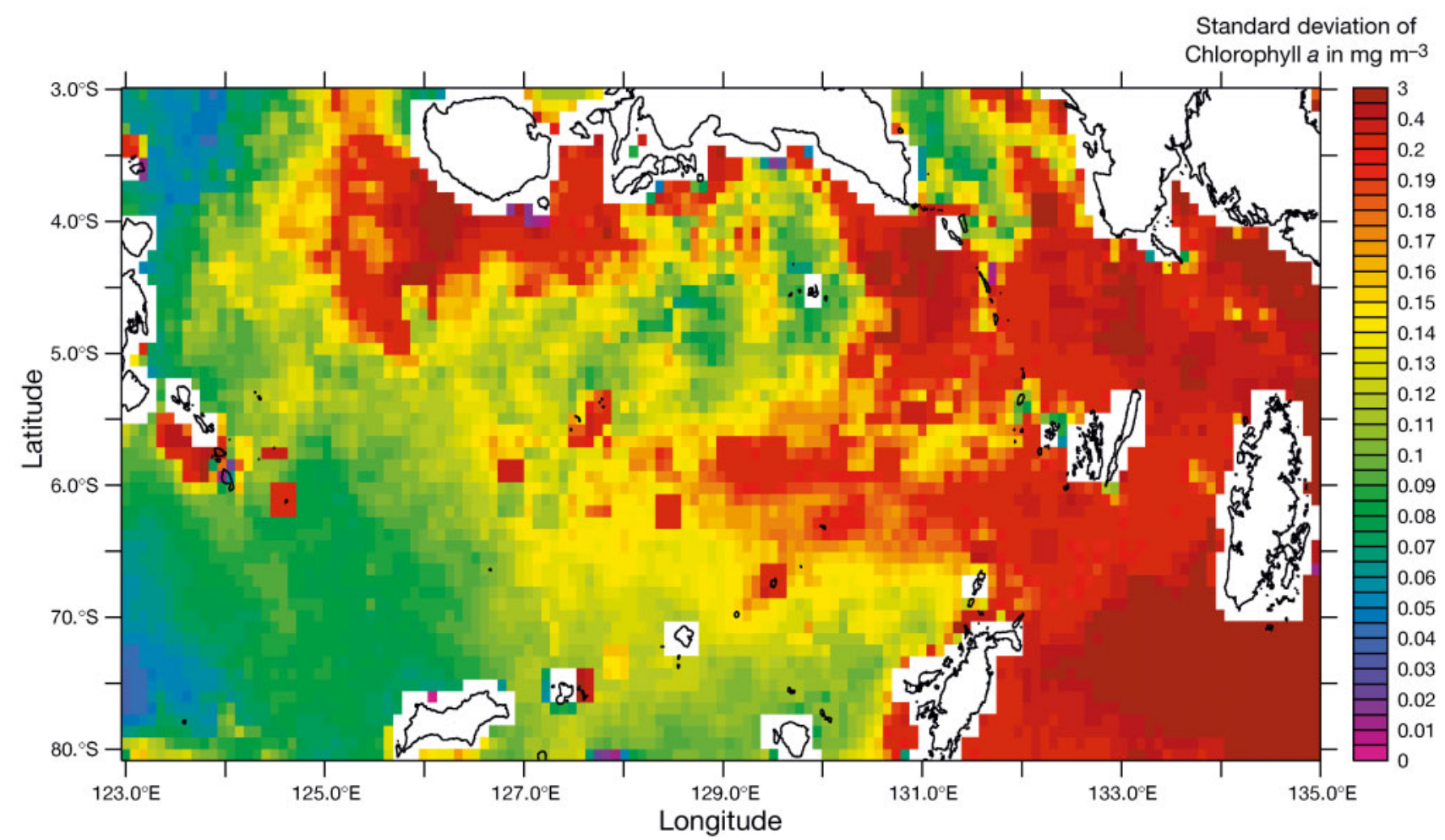

Fig. 8. Standard deviation of remotely sensed chl a using weekly $9 \mathrm{~km}$ SeaWiFS data (September 1997 to December 2000)

deviations in SST were in the eastern Banda Sea. Similarly, SeaWiFS ocean color imagery shows high standard deviations for the eastern Banda Sea (Fig. 8). Differences between SST fields and ocean color imagery are to be expected, primarily because of the higher resolution SeaWiFS data compared to the SST data in question. These differences are most likely to be expressed in close proximity to the smaller islands. Also, the influence of nutrient input from runoff during the monsoons might produce ocean color variability without corresponding changes in SST.

\section{CONCLUSIONS}

We have used the distribution of chl $a$ in the Banda Sea, from both shipboard and satellite data, as an indicator of the dominant physical dynamic in the basin. Both datasets support the idea that upwelling during the southeast monsoon dominates the east/west distribution of chl $a$, and supports higher phytoplankton biomass (and therefore, shallower euphotic depths) in the eastern Banda Sea. The distribution of chl a is directly related to seasonal upwelling in the east, modulated by interannual events such as the El Niño-Southern Oscillation, and the satellite images reveal the related impact of the 1997-1998 El Niño. El Niño conditions seem to strengthen and prolong the productive season in the Banda Sea, extending the time of high chl a concentrations well past the climatological end of the southeast monsoon.

Acknowledgements. The authors would like to thank the captain and the crew of the Indonesian Naval RV 'Baruna Jaya IV' for their support during our time together on the Molucca, Ceram, and Banda Seas. We would like to thank C. Trees for the HPLC analyses, and R. Matear, D. Griffin, G. Cresswell, S. Godfrey, P. Tildesley, C. Rathbone, K. Badcock, and J. Mansbridge, for valuable support and discussions. This study was supported by NASA HQ grant, NAG5-6877, and is LDEO Contribution No. 6487.

\section{LITERATURE CITED}

Alford MH, Gregg MC (2001) Near-inertial mixing: modulation of shear, strain and microstructure at low latitude. J Geophys Res 106:16947-16968

Boely T, Gastellu-Etchegorry J, Potier M, Nurhakim S (1990) Seasonal and interannual variations of the sea surface temperatures (SST) in the Banda and Arafura Sea area. Neth J Sea Res 25:425-429

Bray N, Hautala S, Chong J, Pariwono J (1996) Large-scale sea level, thermocline, and wind variations in the Indonesian throughflow region. J Geophys Res 101:12239-12254 
Ffield A, Gordon AL (1996) Tidal mixing signatures in the Indonesian Seas. J Phys Oceanogr 26:1924-1937

Ffield A, Vranes K, Gordon AL, Susanto RD (2000) Temperature variability within Makassar Strait. Geophys Res Lett $27: 237-240$

Gieskes WWC, Kraay GW, Nontji A, Setiapermana D, Sutomo AB (1990) Monsoonal differences in primary production in the eastern Banda Sea (Indonesia). Neth J Sea Res 25: $473-483$

Godfrey JS (1996) The effect of the Indonesian throughflow on ocean circulation and heat exchange with the atmosphere: a review. J Geophys Res 101:12217-12237

Gordon AL (1986) Interocean exchange of thermocline water. J Geophys Res 91:5037-5046

Gordon AL, Susanto RD (2001) Banda Sea surface-layer divergence. Ocean Dynamics 52:2-10

Ilahude AG (1998) Three and a half decades of oceanographic surveys in the Indonesian waters (1960-1995). In: Cresswell $G$, Wells $G$ (eds) The ASEAN-Australia Regional Ocean Dynamics Expeditions 1993-1995. Proc Symp, Lombok Indonesia, June 1995. AMSAT, Canberra, p 19-28

Ilahude AG, Gordon AL (1996) Thermocline stratification within the Indonesian Seas. J Geophys Res 101: 12401-12409

Kinkade C, Marra J, Langdon C, Knudson C, Ilahude AG (1997) Monsoonal differences in phytoplankton biomass and production in the Indonesian Seas: tracing vertical mixing using temperature. Deep-Sea Res I 44(4):581-592

Longhurst A (1993) Seasonal cooling and blooming in tropical oceans. Deep-Sea Res I 40:2145-2165

Meyers G (1996) Variation of Indonesian throughflow and the El Niño-Southern Oscillation. J Geophys Res 101: 12255-12263

Moore TS II, Marra J (2002) Satellite observations of bloom events in the Strait of Ombai: relationships to monsoons and ENSO. Geochem Geophys Geosyst 3(2)

Mueller JL, Austin RW (1995) Ocean optics protocols for SeaWiFS validation, Revision 1. NASA Tech Mem 104566-25, NASA Goddard Space Flight Center, Greenbelt, MD

Editorial responsibility: Otto Kinne (Editor),

Oldendorf/Luhe, Germany
Mueller JL, Johnson BC, Cromer CL, Cooper JW, McLean JT, Hooker SB, Westphal TL (1994) The second SeaWiFS intercalibration round-robin experiment, SIRREX-2, June 1993. NASA Tech Mem 104566-16. NASA Goddard Space Flight Center, Greenbelt, MD

Patt FS, Barnes RA, Eplee RE Jr, Franz BA and 14 others (2003) Algorithm updates for the fourth SeaWiFS data reprocessing. In: Hooker SB, Firestone ER (eds) NASA Tech Mem 2003-206892, Vol 22. NASA Goddard Space Flight Center, Greenbelt, MD

Susanto RD, Gordon AL, Zheng Q (2001) Upwelling along the coasts of Java and Sumatra and its relation to ENSO. Geophys Res Lett 28(8):1599-1602

Tomczak M, Godfrey JS (1994) Regional oceanography: an introduction. Elsevier, New York

Walker AE, Wilkin J (1998) Optimal averaging of NOAA/ NASA Pathfinder satellite sea surface temperature data. J Geophys Res 103:12869-12883

Waworuntu JM, Fine RA, Olson DB, Gordon AL (2000) Recipe for Banda Sea water. J Mar Res 58:547-569

Wright SW, Jeffrey SW, Mantoura RFC, Llewellyn CA, Bjornland T, Repeta D, Welschmeyer N (1991) Improved HPLC method for the analysis of chlorophylls and carotenoids from marine phytoplankton. Mar Ecol Prog Ser 77:1183-1196

Wyrtki K (1957) The water exchange between the Pacific and the Indian Ocean: Proc Ninth Pacific Science Congress. Institute of Marine Research, Djakarta, p 61-65

Wyrtki K (1961) Physical oceanography of southeast Asian waters. Report No. 2, Naga Report, Scripps Institution of Oceanography, Univ of California, La Jolla

Wyrtki K (1987) Indonesian through flow and the associated pressure gradient. J Geophys Res 92:12941-12946

Zevenboom W (1990) Picocyanobacteria in the Banda Sea during two different monsoons. Neth J Sea Res 25:513-521

Zijlstra J, Baars M, Tijssen S, Wetsteyn F, Witte J, Ilahude A, Hadikusumah (1990) Monsoonal effects on the hydrography of the upper waters $(<300 \mathrm{~m})$ of the eastern Banda Sea and northern Arafura Sea, with special reference to vertical transport processes. Neth J Sea Res 25:431-447

Submitted: March 1, 2002; Accepted: July 4, 2003

Proofs received from author(s): October 6, 2003 